\title{
Challenges of Maintaining Housing Structures in the Old City of Hebron
}

\author{
Wisam Shaded \\ Palestine Polytechnic University, Palestine
}

Received March 22, 2021; Revised May 12, 2021; Accepted September 20, 2021

\section{Cite This Paper in the following Citation Styles}

(a): [1] Wisam Shaded, "Challenges of Maintaining Housing Structures in the Old City of Hebron," Civil Engineering and Architecture, Vol. 9, No. 6, pp. 1970-1984, 2021. DOI: 10.13189/cea.2021.090626.

(b): Wisam Shaded (2021). Challenges of Maintaining Housing Structures in the Old City of Hebron. Civil Engineering and Architecture, 9(6), 1970-1984. DOI: 10.13189/cea.2021.090626.

Copyright $\odot 2021$ by authors, all rights reserved. Authors agree that this article remains permanently open access under the terms of the Creative Commons Attribution License 4.0 International License

\begin{abstract}
This paper discusses the importance of preserving traditional dwellings, especially those located within the boundaries of cities and old towns. It addresses the most important problems and obstacles that prevent the preservation of these buildings, as well as highlights cultural heritage and its importance in preservation process. This is done using a descriptive analytical approach; including documentation and questionnaires as its main tools. The study raises questions about maintaining building structure and its components of cultural significance without compromising its material and cultural essence. The study is focused on the Old City of Hebron and presents the difficulties that affect the livelihood and living conditions of people living within its boundaries. The study finds that there are necessary changes that are required to facilitate living in the Old City, including maintenance and re-fating, changing tiles and restructuring of plumping and sanitation facilities. These changes however, need to take preservation of the structural elements, and cultural heritage into account. The study concludes that there is a need for more studies to examine the structure and the identity of dwellings in the Old City which will help in future efforts to preserve the cultural essence of these dwellings and protecting them from structural changes, while making them inhabitable for people.
\end{abstract}

Keywords Restoration Work, Preservation of Historical and Cultural Heritage, Analytic Descriptive Research, Hebron, Palestine

\section{Introduction}

The process of preserving cultural property in ancient cities is one of the topics that can take multiple different dimensions. These differences mainly lie in the nature of the property and the main goal of the preservation process. There could be various opinions regarding the same problem. Still, they are undoubtedly aimed at one goal: to limit the collapse and deterioration in the state of cultural property by following several steps to help achieving this goal for Preservation. Although preservation and restoration work can be considered as a complex research and production process, due to the fact that attention must be paid to the external elements, internal space and decoration [1]. The interest in Preservation goes back hundreds of years. Feilden defines the preservation process as "the procedure followed to prevent damage and manage changes dynamically and include all processes that would stop wear and tear [2]. It embraces all works that prolong the life of our cultural and natural heritage and includes minimum effective measures if possible so that the procedure is reversible without biasing interventions. The Preservation of historical buildings is established through legislation through the inclusion and scheduling of buildings and ruins, through systematic inspections and documentation of them, and the aim is to present it to those who use it in order to look at historical buildings with astonishment and read the technical and humanitarian messages that these buildings possess, other than Preservation as a concept and as a process is defined as a measure that ensures that cultural property does not become damaged or decayed [2]. The inherited urban 
fabric represents a planning and architectural study through which architectural styles can be inspired. This heritage constitutes a historical and aesthetic value in addition to the symbolic and spiritual aspect [3].

The process of preserving housing in old cities is subject to a number of physical, urban, and economic aspects [3]. However, the most important element that must be included in the process is the human being and his social requirements and the needs that ensure continuity in living in the old housing. Living in old dwellings has many effects that cause a challenge in the preservation process; this includes changes that the inhabitants of these dwellings may make, whether by adding elements and additions that may be extraneous to the original component or removing some old original components and replacing them with modern materials. Also, technology additions that may be added to the residential building are considered a basic requirement in modern housing, including electricity, plumbing, internet, and others, which may be extraneous to the visual, structural, and characteristic of old dwellings. This study deals with these aspects by giving practical examples that illustrate A group of problems facing the preservation process, a special case in Hebron.

\section{Problem statement}

The lack of studies related to the process of preserving traditional housing in the city of Hebron and the constant need for documentation to preserve the cultural heritage due to the great danger that the Old City faces as a result of the conditions surrounding it and the increase in the suffering of Palestinian citizens and their properties, a large part of which has come under the security control of the town's occupation army, and that a large part of these dwellings require documented studies that explain and analyse the conservation processes that took place in them and the problems that emerge due to the many factors that we will mention in this study and the nature of these dwellings according to a scientific, historical and contextual approach. In this context, the study examines the following questions:

- What are the obstacles that prevent reaching the desired goal of preserving the structural elements and the cultural components without prejudice to the material and cultural essence?

- What are the difficulties encountered in housing in the Old City, what are the causes, results, and impacts of these on preserving houses in the Old City?

\section{Objectives}

The study aims to uncover the reality of living in old houses in the Old City of Hebron and identify the factors and causes affecting their Preservation by explaining the conditions of residential buildings and the interventions made to preserve them and enable residents to live in them.
Also, effects of the structure in traditional housing, and proposals to enhance the factors of resilience and survival.

\section{The importance of the study}

The study has theoretical and practical implications. It sheds light on the historical, cultural, and aesthetic importance of the buildings in the Old City of Hebron and the urban fabric that contributed to giving urban and planning models and the original and unique aesthetic dimensions that they reflect. The main obstacles facing the process of preserving housing are presented from the point of view of its residents and those in charge of the process of Preservation, studying the condition of residential buildings and analysing the political, social and family role of these housing from a viewpoint close to reality and in practice.

\section{Previous studies}

Study dr.Iman Assi[4] from An-Najah National University, Nablus, Palestine, entitled Cultural Heritage, and Sustainable Development: The Role of Local NGOs in Rehabilitation of Historical Cities in Palestine (2006). This paper discusses the role of local organizations in Palestine in the field of conservation in historical cities as a case study. It also critically assesses the contributions and limitations of NGOs, and it discusses accountability and performance in achieving a sustainable approach. It also stresses the importance of emphasizing the values inherent in historic cities. The study indicates the existence of a certain necessity in the preservation process. The study concluded on the protection and promotion of these values and support for the rehabilitation of cultural property as an integral part of the overall human development.

The second study by Dr. Amira Al-Nukaly and Dr. Ahmed Al-Sarraji[5], Sustainable Heritage Development: Learning from Urban Conservation for Heritage Projects in Non-Western Contexts Published in the European Journal of Sustainable Development (2013). The paper examines the definition of Preservation as an umbrella term that covers a broad range and spectrum of issues that can be classified under four categories: social, physical, cultural, and environmental concerns, as it manifests itself as an evolutionary process that includes the Preservation, restoration, and adaptation of ancient structures. The paper aims to explore the advantages of six conservation and rehabilitation projects that have received great coverage and recognition at the national and international levels and highlight them in this article to work as a prototype for similar models worldwide. The characteristics of historical regions and the lives of the communities that live there must be preserved, and the adaptation of physical structures and activities to each other must be a requirement of conservation today. 


\section{Introduction about the city of Hebron}

The history of Hebron goes back to 5500 BC. It is one of the oldest cities in Palestine and was inhabited by the Canaanites in $3500 \mathrm{BC}$, and their remains are still there. The city of Hebron derives its importance from being the city of the prophets, and its name is taken from Khalil al-Rahman, our master Abraham, peace be upon him, the father of the prophets. And when his wife Sarah died in the meantime, he buried her in the Cave of Machpelah, which he had bought to be a grave for him and his family [6].Hebron was previously called Qaryat Arba, meaning city number four, in reference to the Arab Canaanite, Abu al-Anakin. It is the tribe whose homes were on the mountains extending between Hebron and Jerusalem. Its name remained for 1400 years until the Jews entered it after the defeat of the Canaanites at the hands of Joshua, and Caleb changed the name of the city to Hebron in relation to his son. The Romans ruled Hebron for a period of time, and its castle was built next to the tomb of Abraham and their remains remain there. Hebron entered Islam in the era of the Islamic conquests, and the governors took care of it to remove the pagan monuments that existed in it [7]. The city remained under Islamic rule Until the Franks usurped it in 1099 AD, when they demolished the Ibrahimi Mosque in Hebron and erected on its ruins a fortress for their knights. They also built a church and a monastery for their monks. In the year 1168, Hebron became a center for the diocese during the Crusades, and the Ibrahimi Mosque was transformed into a church in 1171-1172 A.D. When Saladin recaptured the city in 1187 A.D., he transformed the church into a mosque and moved the Ashkelon pulpit to it, which is still there [7], and he added some additions to it, the most important of which is the hallway [8]. It was divided into two stages: the Turkish Mamluks and the Circassian Mamluks. The population of Hebron before the arrival of the Mamelukes reached 50 thousand people. It increased after the Mamluks entered it, and many of the buildings in the Old City date back to the Mamluk period in their foundations [9]. The rest of it dates back to the Ottoman period due to the long period of time during which the Ottomans ruled the city of Hebron, and that was following the Battle of Marj Dabiq, north of Aleppo, in the year 922 AH: $1516 \mathrm{CE}$, figure 1 and figure 2 Hebron came under the rule of the Ottomans in $922 \mathrm{AH}$ : 1516 AD [7], and their rule continued there until 1917, except for the Egyptian period that began in 1831-1840 when Ibrahim Pasha seized Hebron and soon returned to Ottoman rule[7]. In the year 1918, January 4, Hebron fell under the British Mandate and continued until 1948, when the Palestinian Nakba took place, and the Jews seized a large number of Palestinian lands. By the time the Jews seized the entire Palestinian land. After the Oslo Accords took place, Hebron entered under a partial administration of the Palestinian Authority and the Israeli Occupation, which remains to this day [10].

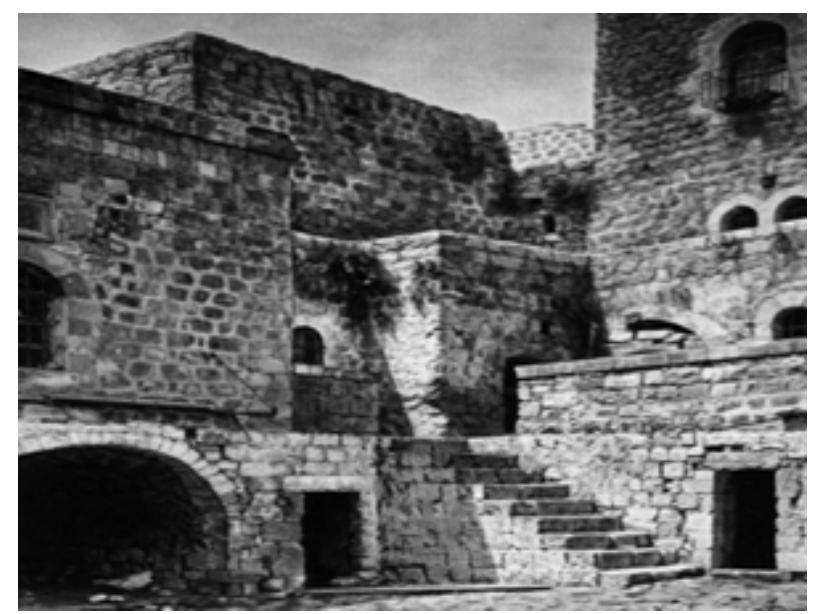

Figure 1. The Agency Market in the Old City of Hebron taken in 1925. Source: The Pictured History of the Old City of Hebron

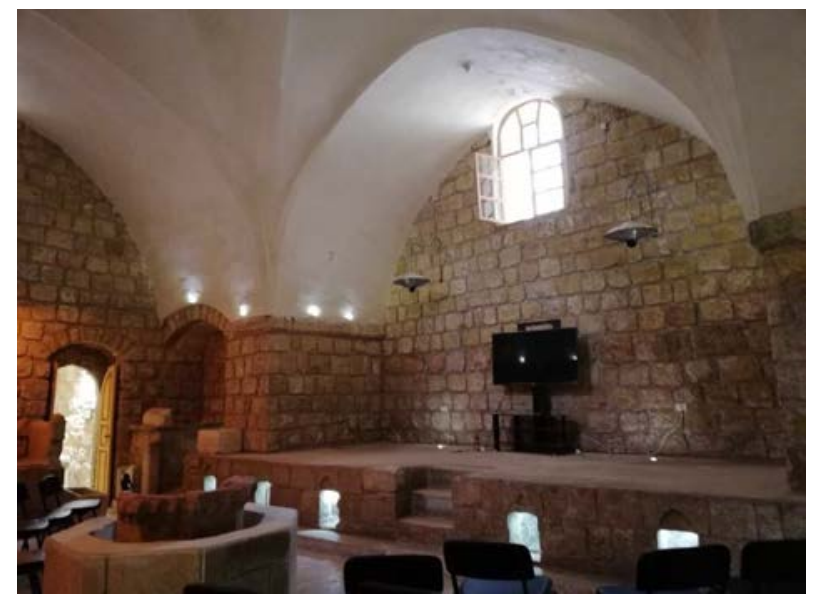

Figure 2. The Hammam which Al-Saleh Qaitbay built during the Mamluk time in the year seventy-nine and six hundred. Source The Researcher 2020

\section{The Preservation of cultural properties in the city of Hebron}

Voices calling for the Preservation of cultural property rose due to the dangers which the Old City of Hebron was exposed to as a result of the Occupation; occupation authorities had followed a policy of displacement and emptying of the Old City of its people since it was occupied in 1967 when the population at that time was 10 thousand citizens (Reconstruction Committee Hebron. 1999). The population keeps declining as a result of the Israeli authorities' systematic policy of displacing the population, including blockade, curfews, and starvation. The number became approximately 400 citizens In 1996 [11]. Despite all the attempts made by many local institutions, including the University League in 1983, to preserve the components of the Old City of Hebron [11], these efforts faced many difficulties and challenges By the Occupation authorities.

After the Oslo Accords and the entry of the Palestinian National Authority in the areas of the West Bank in 1996, 
the Hebron Rehabilitation Committee was established when President Yasser Arafat issued a presidential decision to form a committee of personalities, institutions, and actors from the Hebron governorate[12]. One of the most important objectives of this committee was to confront the issues with Jewish settlements in the Old City. Blocking roads to the outposts and not allowing Israeli settlers to seize more houses in the Old City area and to work out a plan to re-house the residents that were displaced as part of the process.

It also focused on a plan to rehabilitating, as well as preserving the formative structure of the old town by preserving the urban fabric and the cultural and aesthetic components and also trying to restore life to the Old City. This effort was to establish more possibilities for service, health, recreational and social centers that serve the population and strengthen the basic foundations of life in it [12].

\section{The Old City of Hebron is an exceptional global site}

Architectural heritage is classified as part of the cultural heritage of a specific group of people [13]. Civilization arose with man, who was always the fixed basis for it and ages.

The spaces, and urban environments have proven their originality and value in the face of constant, continuous and sometimes intermittent change. The World Heritage Committee and with the World Heritage Center, which consist of the president, vice-presidents and the rapporteur of the committee consisting of representatives of all countries provide an important force in preserving the identity and heritage of urban spaces.

The parties generally meet once a year, and its primary function is determining the nominations submitted by the state parties regarding the distinct global cultural value and the natural characteristics that must be protected under the Convention, and the inclusion of these properties on the World Heritage List. They also determine which method and under what conditions the resources in the Global Heritage Fund can be used more effectively to assist state parties in protecting their properties of outstanding universal value [14].

The Arab group led by Palestine submitted a request to include the Old City of Hebron on the World Heritage List protected and to indicate that it is an Islamic city [15]. The meeting took place on July 7, 2017, in Krakow, Poland. As a result, the Old City of Hebron was registered on the World Heritage List as an emergency based on the criteria set on the List of World Heritage in Danger within the previous clauses. Registering the World Heritage Property (WHP Ref. 1565) on the World Heritage List as a state of emergency based on criteria 2, 4 and 6, and on the List of World Heritage in Danger after acknowledging that it faces serious threats. The World Heritage Committee took immediate action, and the Committee (WHCom Decision:
41 COM 8B.1) adopted during its forty-first session (Ministry of Tourism and Antiquities, 2019. p3).

\section{Factors affecting the preservation process in Hebron}

The theoretical concepts related to preserving the components of civilization, especially housing, require seeking to find the right mechanism in its application, which includes finding the appropriate ground that helps to apply all ideas and theories and turn them into reality. Feilden mentioned in the writing guidelines for managing cultural and world heritage sites; that a successful maintenance strategy requires the participation of properly qualified professionals to monitor and diagnose the causes of damage, and requires an inspection and reporting process for the site committee. Professionals must be employed in the process as well as supervisors, craftsmen and all ranks of workers [14]. The work of a plan of action that includes a number of committees and a number of entities that must be involved in the process to ensure the success of these plans may require the Municipality of Hebron, Palestine Polytechnic University and other local and international institutions to work out an initial plan that included a vision to maintain the goal of ensuring the quality of life for the residents of the Old City as well as care by preserving the historical values and cultural uniqueness of those buildings and working to improve them [16].

The plans that have been put in place to preserve traditional housing in the city of Hebron face a number of challenges and problems related to a number of factors, including the specific restrictions due to the Occupation, including laws related to land use and building specifications, as well as the difficulty of moving between houses adjacent to each other and finally the visual distortion imposed by the occupation authorities on the general landscape of housing and its natural extension [16][17].

\section{Procedures for housing maintenance in the Old City}

The housing maintenance process in the Old City passes through several stages. When allocating the housing issue, in particular, it is possible to notice the intersection of the maintenance and restoration process while maintaining that they together form a triangle for the same process and plans intersect with each other and share the following stages:

First stage: determining the residential building in terms of value and importance [18] and is classified as it includes the characteristics of the housing and its general condition in terms of building materials, available living spaces, and the social and professional status of its residents [17].

Second stage: Documentation and this is done through several methods, including referring to records and maps 
[18] and conducting a field survey of the main façades and studying their patterns and stages of development [17].

Third stage: Designs and plans are made according to conservation standards [18], and this process must be subject to further scrutiny to maintain the basic standards

Fourth stage: Decision-making and analysis, which must follow the scientific and analytical method for all information [18]. At this stage, a team of specialists from all disciplines that contribute to achieving the goal of the preservation process must be guided by us; we mention engineers in all specialties, craftsmen and specialists in the legal field, and socio-economic and others.

Fifth stage: Take maintenance measures and follow up on the residential building to keep it in good condition [18].

\section{Materials and Methods}

The study follows the descriptive and analytical scientific method through various means of interviewing and observation and using various photography tools, computer drawing, documentation, and making plans and studies by scanning and documenting the houses used as examples in this study.

\section{Study tools}

The study used references from literature, books, letters, published scientific research, and other accessible written sources. It also used basic observation tools, such as questionnaires for monitoring and analysis, as well as photography.

\section{Results}

This part explains the results through the process of analysis in which several tools were used. Such as observation, drawing, photography, and uploading, in addition to information taken from the engineers from the Hebron Rehabilitation Committee and the representative population of the study community in the form of a questionnaire distributed to the people and specialists to measure discussing the obstacles and problems facing the preservation process. The study adopted a selected sample of two models: the old town dwellings, which have been maintained and restored by the Hebron Rehabilitation Committee, and citizens have been housed in them, and several specifications apply to these samples, including the housing that was selected divided into two parts, a section whose owners from ancient times still live in it and part of the residents who rented these buildings. The residences that were studied have been restored by the Hebron Rehabilitation Committee and are still in need of further maintenance and rehabilitation.

\section{Study samples}

Model 1: Fawzi Al-Rugby House:

Description of the building and the operations of the governorate that took place in it: The house is placed in the Bani Dar neighbourhood, which is located to the west of the Al-Ibrahimi Mosque, and the origin of this neighbourhood dates back to the Mamluk period, and it is one of the best neighbourhoods, according to the sources. The building is based on the traditional construction method in terms of the presence of the propeller node system (the Crusader dome) as a system adopted in the roofing. The decoration of the interior ceilings of the residence shows a group of stucco decorations, especially in the bedroom. The maintenance operations that took place in the residential building are as follows. First: The bedrooms were serviced and re-painted with water-based paint, using white plaster and construction. Second: To completely change the existing tiles of the building. Third: Restructuring the health and sewage network. Fourth: Adding the kitchen and bathroom space to keep pace with modern technologies and help add sinks to that. Fifthly: the installation of municipal seedbed floors, ceramics, and stone tiles. Sixth: Additions to the building, which is the roofing in the open yard, zinc was used in this type of loading.

\section{Governorate Problems of the Residential Building}

Fawzi Al-Rajabi house came to be a living example of a connected residence in a homogeneous neighbourhood most of the time, as it is most likely that whoever lived in this housing complex was composed of a homogeneous group of relatives, and it is evident that the people of the neighbourhood shared the courtyards, which indicates the interconnectedness between each other. The work of the fence separating the adjacent courtyards from each other, and the residential building consists of three levels, which were basically a building for one family and for the variation of time periods. It poses a remarkable challenge to the design unit, especially in one interface. Fawzi Al-Rugby's residence suffers from the following problems:

First: Although Fawzi Al-Rajabi's house has been restored and equipped for housing, we find some inconsistency in the interior design of the residence and the need to connect the parts of the space that is characterized by the beauty of the ceilings and the distinctive interior division of the residential building. The bedrooms did not match in shape and design with the space of the room and the rooms. The seating does not have much furniture and needs to be arranged to suit the old dwelling.

Second: The old and modern additions that occurred to the residential building with materials not suitable for the state of the building, along with previous bad interventions by materials and methods that affected its 
aesthetic component. The kitchen and its related areas of cooking, storage, and cooling did not meet the requirements of modern housing and needed to be redesigned to suit the measurements and conditions of the old dwelling. Three types of floors were found.

Third: The human intervention, which was represented in the work of repairs and changing the features of the building, from opening some passage and using inappropriate materials such as clay pores, which closed the pores of the stone and changed the aesthetic value of the building by hiding the natural stone of the building. Drainage pipes have also been extended, which shows the latest visual distortion of the building on the facades. The use of bricks as a wall separating the room and some of the building's walls and acting as an outer layer for some parts of the façades changed the original components of the residential building as well as the use of reinforced concrete to build columns to add new floors to the building for construction reinforcement that changed the original load ratios and the design of the original figure 3 and figure 4.

Fourth: The damage and destruction of all wooden cabinets inside the walls that were dislodged and dispensed with permanently and what remained of their openings affected the original internal aesthetic component of the residential building figure 5 .

Fifth: The house suffers from many natural problems, such as rain, earthquakes, dampness, and kohl, Which creates a constant challenge in the residential building's maintenance process to preserve it.

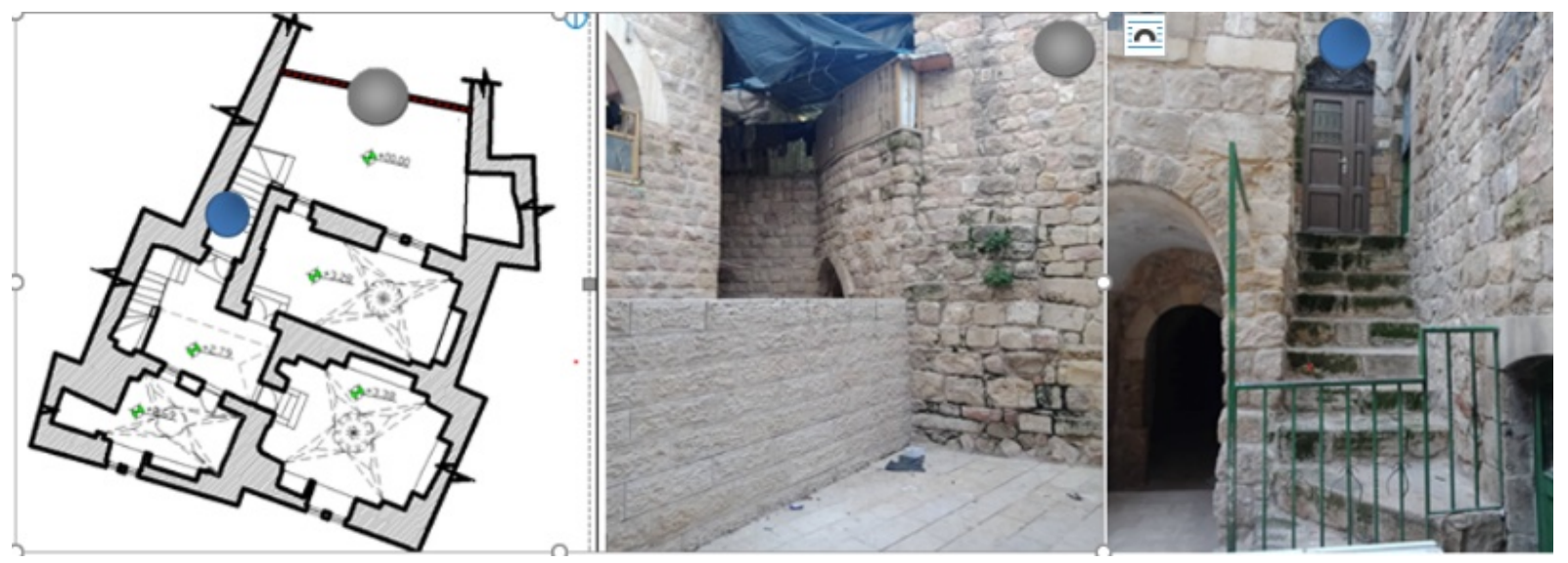

Figure 3. Main entrance and the wall that separates the monsters for the families who live next to the Al-Rajabi residence in the Bani Dar neighborhood and was placed to separate the spaces and give privacy to the Fawzi Al-Rajabi residence.

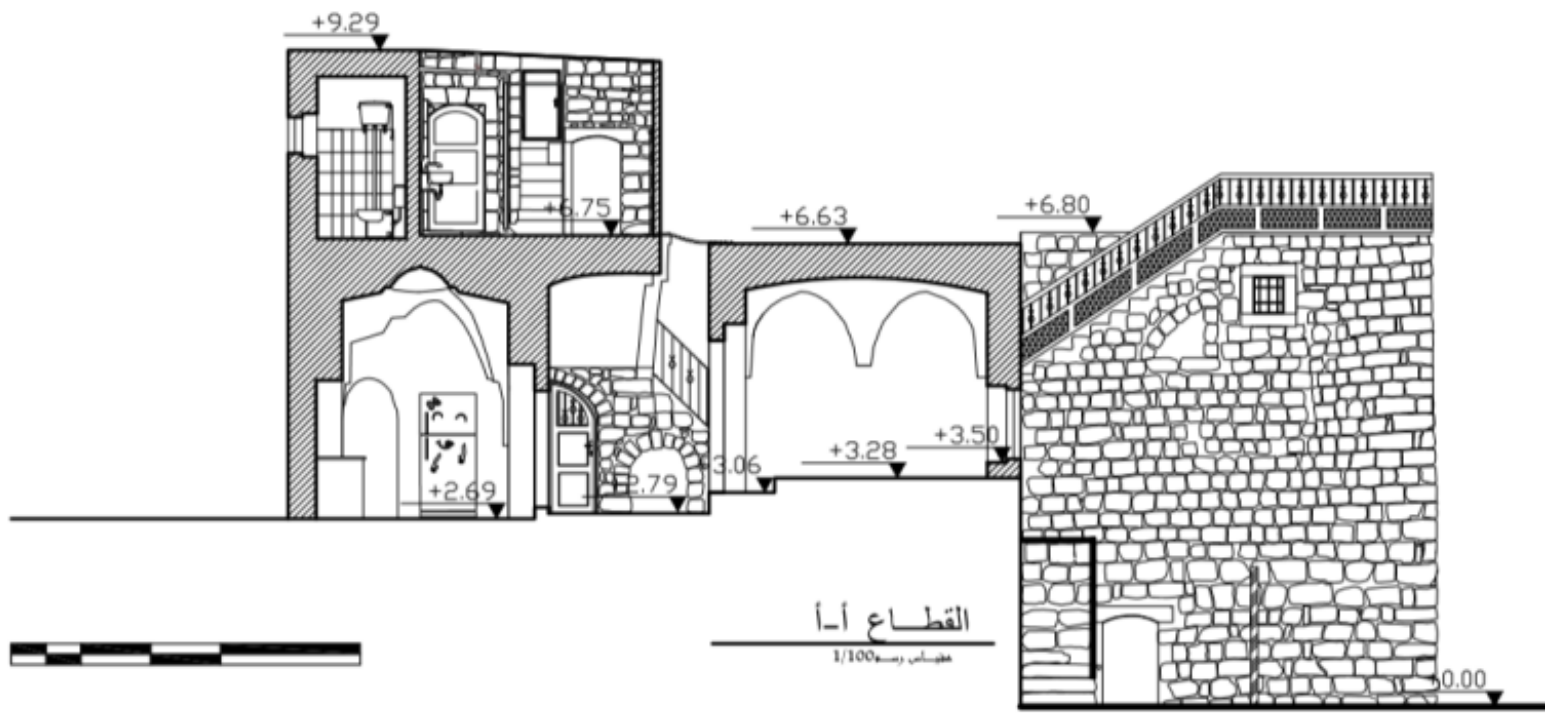

Figure 4. Sectors (A-A) of Fawzi Al-Rajabi House, source: Researcher drawing 2020 

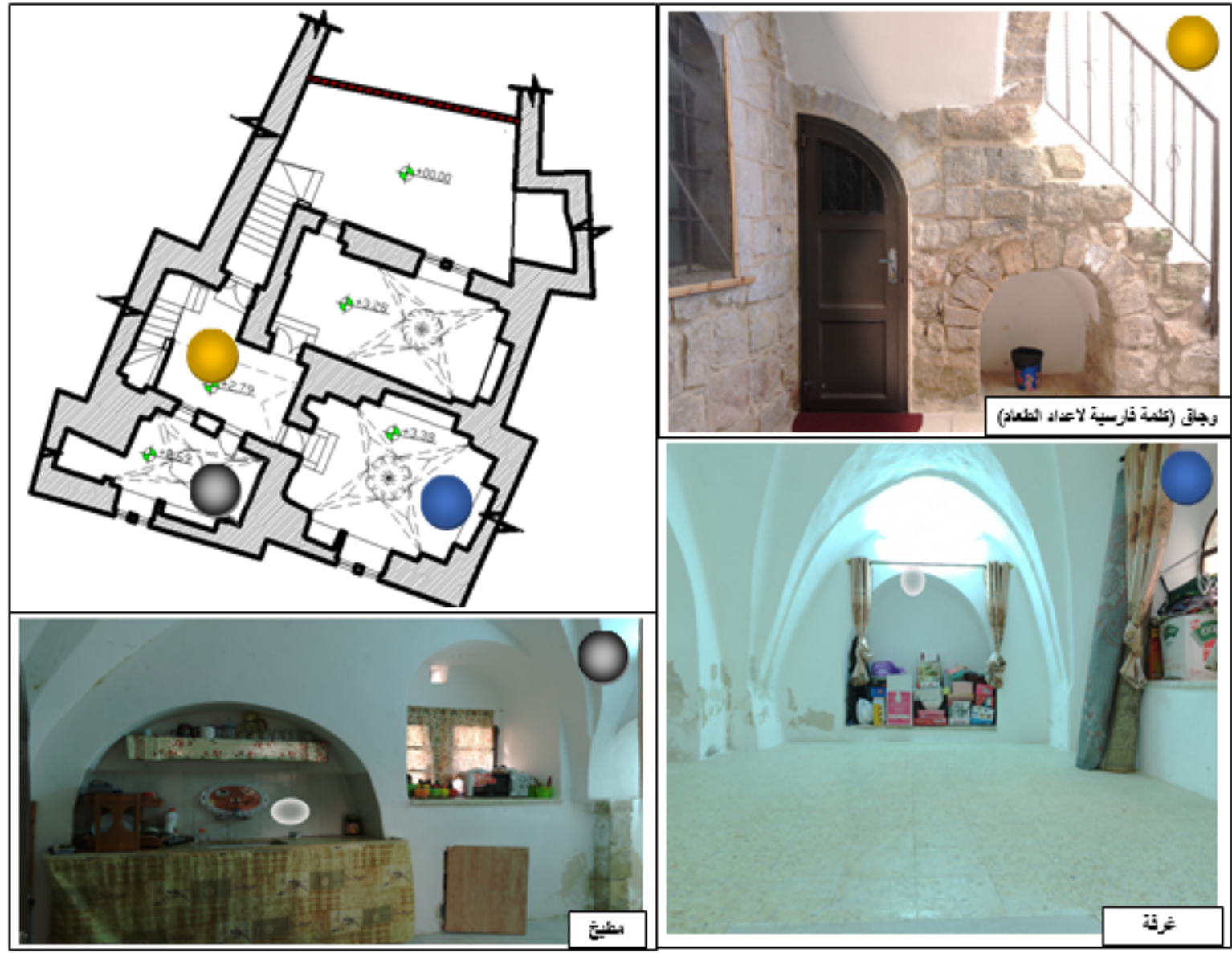

Figure 5. Some of the internal details of Fawzi Al-Rajabi residence, including the internal lockers, Al-Bahah 2020

Model 2: Al Qafisha House:

Description of the building and the operations of the governorate that took place in it: The housing is considered part of the Al-Harbawi family complex, which is located in the heart of the Old City of Hebron at the intersection of two main streets, namely the Kasbah market, which extends from Ain Al-Askar Square in the northwestern region to the Ibrahimi Mosque in the south, and the second is the milk market that extends to the cobbled market area. Preserving the residential building was carried out as follows: First, it required adding new parts of the building and the necessary development of the new requirements of the housing to create special areas such as the bathroom. Secondly, concrete partitions were made next to the traditional building, cutting, re-extension, and kitchen establishment. Third: Maintenance of the balcony at the front façade. Fourth, repairing the roof from the outside by adding insulating materials for insulation and protection from external factors. Fifth: Maintenance of the architectural openings, doors, and windows.

\section{Governorate Problems of the Residential Building}

By looking at its front façade and like other dwellings that were formed through different stages, we find it difficult to find a design unit for it as it suffers from the diversity of patterns and designs and the overlay of designs evident in one façade figure 3-4, and this building consisting of three levels has been monitored Four different styles of architectural openings, including doors and windows, including rectangular and motors, including semicircles, and curves, almost all on the same facade. The location of the Qafaisha residence constituted an important factor in easy accessibility due to its location relatively far from the heart of the Old City, which suffers from bottlenecks due to the difficulty of vehicle access to it, and the residential building suffers from the following problems:

First, the nature of the building based on broken and narrow entrances is somewhat difficult to connect a number of components that need when entering them, such as large pieces of furniture, which require small standard specifications of furniture pieces to be able to be connected to the interior of the house figure 7. 


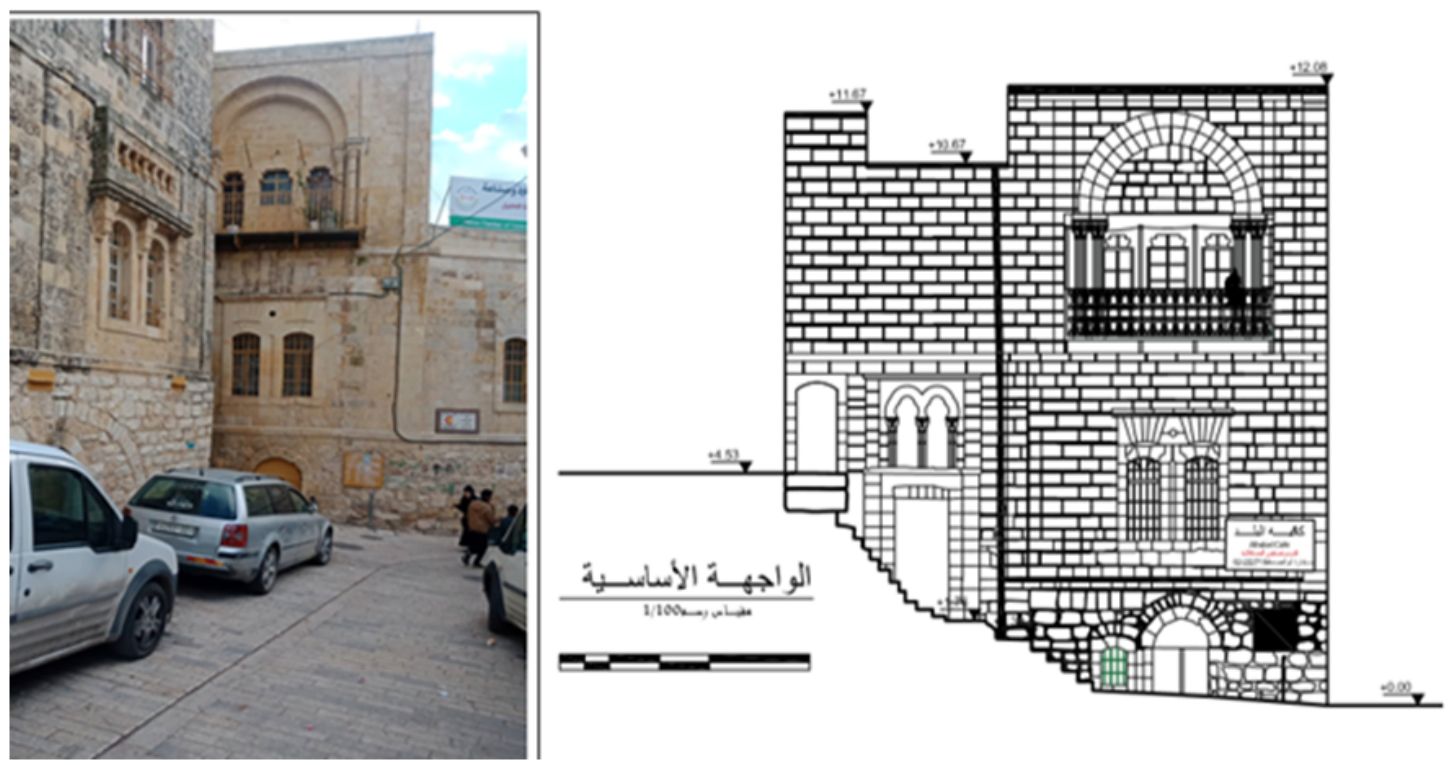

Figure 6. Details that appear in the main façade of the Al Qafaishah house, source: the researcher 2020.

Second, the interior design of the residence did not take into account many of the design aspects of the internal distribution and the requirements of modern living, as well as the house needed to make a number of adjustments in the floors when performing restoration work for it, either to damage the previous floors or the need to establish underfloor extensions to establish sanitation, electricity and the Internet figure 8.

Third, despite the introduction of two kitchens in the Qafisha residence, the original design of the residential building was not taken advantage of from the kitchen and its accessories in places for cooking, storage, cooling, and the bathroom. With changing the addition of tiles to some of the walls at the sink, and the cabinets need to be redesigned to fit the kitchen space.

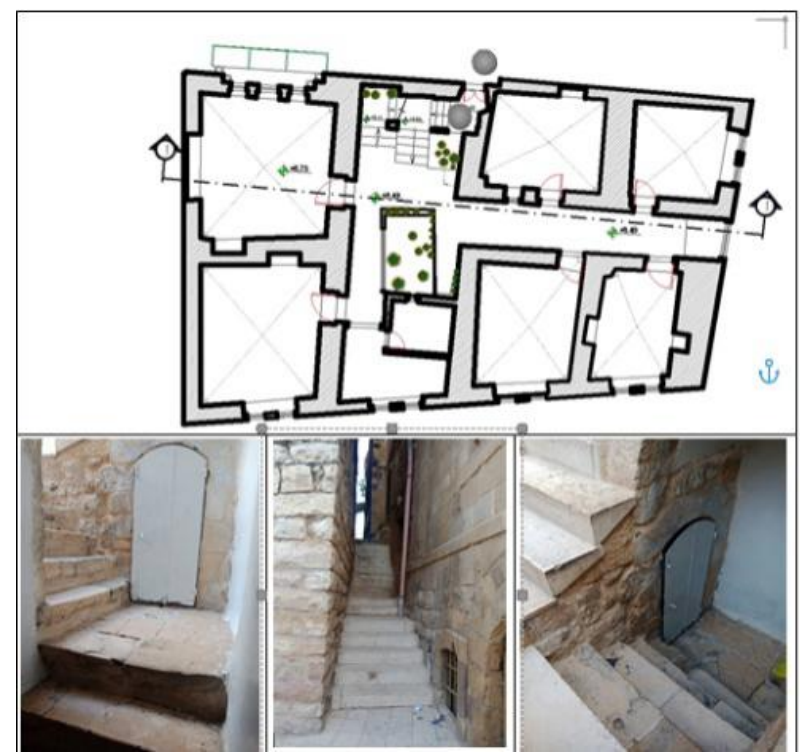

Figure 7. represents the broken entrance to the Al-Qafaisha residence with the stone stairs and is located in the horizontal projection. Source The researcher 2020
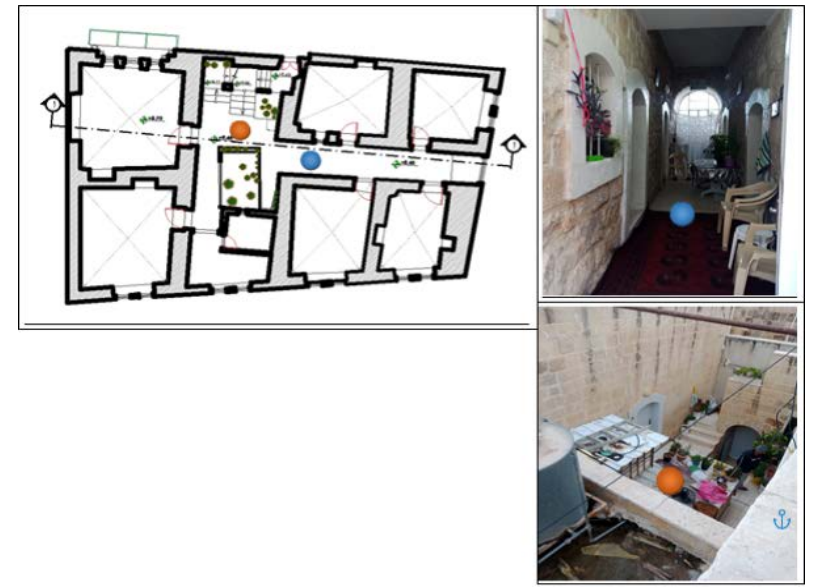

Figure 8. shows two types of courtyards in the dwelling of the Qafaisha family: the first is the roofed courtyard and the second is the main open courtyard

Fourth, wall cabinets as an essential component of the house that have not been maintained and with a model of a wall cupboard that is not restored and is subject to damage due to some factors, including lack of care and natural influences, which constitute a danger. It is difficult however for residents to make good use of them and the existing space, also the process of preserving them poses a challenge to the owners and the parties involved in preserving the aesthetic and cultural components; which leads to them being neglected and destroyed.

Fifth, the Qafisha house suffers from many natural problems such as rain, earthquakes, dampness, fungi, and cracks that affect the structural, constructional, and aesthetic structure of the residential building, requiring constant maintenance follow-up of its condition for this type of old housing.

Sixth, human intervention: It is represented by the work of repairs and changing the building features by opening some openings and using inappropriate materials such as 
thrash, which closed the stone pores and changed their color. It clearly affected the visual landscape of the apartment building.

\section{The questionnaire}

Preface: In order to reach results that address the analytical aspects of the subject of the study, a questionnaire was prepared that helps describe the method and procedures that were used to address the answer to the study's questions and verify them with regard to the issue of housing preservation and the obstacles. Information containing a number 10 was exposed. In his words, the study sample members were asked to determine their response to what each statement describes according to the graduated five-year Likert scale that consists of strongly agree, neutral, strongly reject. Which is useful in measuring the most important problems faced by the old housing in the Old City It is aimed at specialists and residents in the process of maintaining, restoring and documenting housing in the city of Hebron. In this section, the researcher tries to answer the question: What are the obstacles that prevent reaching the desired goal of preserving the structural and cultural component without compromising the material and cultural jewel? The researcher distributed 30 questionnaires to the target audience, and 30 participants responded, as they returned the questionnaires after filling them with all the required information, i.e. $100 \%$ of the target population.

\section{Description of the questionnaire}

The questionnaire consisted of three sections: The first section: It includes the personal data of the study sample members, as this part contains data about age, educational qualification, and nature of work. Section Two: This section contains 10 statements. The study sample members were asked to specify their response to what each statement describes according to the five-graded Likert scale, which consists of strongly agree, neutral, strongly reject. Section Three: This section contains 4 questions. The study sample participants were asked to specify their response to the mentioned options

\section{The questionnaire axes in detail}

The first axis: Description of the study sample according to personal data: 1- Age: Table 1 shows that the age group for the majority of the study participants is 41-60 years, where their number is 14 participants with a percentage of $46.7 \%$, followed by those in the age group 61 years and over with 9 participants, at a rate of $30 \%$, while the number of those in the age group 40 years and less reached 7 participants, and they constitute $23.3 \%$.

The questionnaire in detail: First we collect personal data about subjects: 1 - Age: Table 1 shows that the age group for the majority of the study participants is $41-60$ years, where their number is 14 participants with a percentage of $46.7 \%$, followed by those in the age group 61 years and over with 9 participants, at a rate of $30 \%$, while the number of those in the age group 40 years and less reached 7 participants, and they constitute $23.3 \%$.

Table 1. frequency distribution of study participants according to age Source: Researcher preparation, from the field study, 2020

\begin{tabular}{|c|c|c|}
\hline Age categories & Number of people & Percentage \\
\hline Younger than 40 & $\mathbf{7}$ & $23.3 \%$ \\
\hline $41-60$ & $\mathbf{1 4}$ & $46.7 \%$ \\
\hline Over 60 & $\mathbf{9}$ & $30 \%$ \\
\hline Total & $\mathbf{3 0}$ & $100 \%$ \\
\hline
\end{tabular}

Academic qualification: It is clear from table 2 that the scientific qualification of the majority of the study participants is below the university level, where their number is 22 participants and they constitute $73.3 \%$, followed by those whose scientific qualification is a university where their number reached 6 participants and they constitute a percentage of $20 \%$, while the number of those with a higher academic qualification was two participants, at a rate of $6.7 \%$.

Table 2. frequency distribution of study participants according to academic qualification. Source: Researcher's preparation, from the field study, 2020

\begin{tabular}{|c|c|c|}
\hline Qualification & Number of people & Percentage \\
\hline $\begin{array}{c}\text { Basic education/ no } \\
\text { undergraduate degree }\end{array}$ & $\mathbf{2 2}$ & $73.3 \%$ \\
\hline Undergraduates & $\mathbf{6}$ & $20 \%$ \\
\hline Postgraduates & $\mathbf{2}$ & $6.7 \%$ \\
\hline Total & $\mathbf{3 0}$ & $100 \%$ \\
\hline
\end{tabular}

Occupation: It is clear from table 3 that the nature of work for the majority of study participants is trade, as their number reached 17 participants and they constitute $56.7 \%$, followed by those whose nature of work management has 5 participants and the percentage of $16.7 \%$, followed by those whose job nature is engineers and employees with 2 participants, and by $6.7 \%$ for each of them.

Table 3. frequency distribution of the study personnel according to the nature of work. Source: Researcher's preparation, from the field study, 2020

\begin{tabular}{|c|c|c|}
\hline Occupation & Number of people & Percentage \\
\hline does not work & $\mathbf{1}$ & $3.3 \%$ \\
\hline House wife & $\mathbf{1}$ & $3.3 \%$ \\
\hline dealer & $\mathbf{1 7}$ & $56.7 \%$ \\
\hline Director & $\mathbf{5}$ & $16.7 \%$ \\
\hline Engineer & $\mathbf{2}$ & $6.7 \%$ \\
\hline A builder & $\mathbf{1}$ & $3.3 \%$ \\
\hline Officer & $\mathbf{2}$ & $6.7 \%$ \\
\hline Welding technician & $\mathbf{1}$ & $3.3 \%$ \\
\hline Total & $\mathbf{3 0}$ & $100 \%$ \\
\hline
\end{tabular}


The second part of the questionnaire: The second part included a number of questions about the restoration process.

1. The Reconstruction Committee does sufficient work to preserve the old housing: The answer for the participants was I agree, as their number reached 13 participants, and they constitute $43.3 \%$, followed by those whose answer is strongly agree and neutral with 7 participants, at a rate of $23.3 \%$ each, while the number of those who answered disagree was 3 participants, at a rate of $10 \%$, no participant answered with strongly disagree.

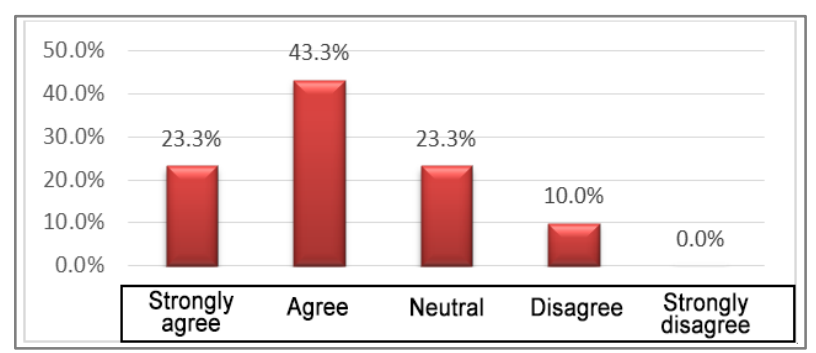

Figure 9. the researcher preparation, from the field study, Source: Excel program, 2020

2. The houses are documented thoroughly before maintenance: The answer for the majority of the participants is I agree, as their number reached 18 participants and constituted $60 \%$, followed by those whose answer was neutral with 7 participants and the rate of $23.3 \%$ While the number of those who answered strongly agree 5 participants, a rate of $16.7 \%$, no participants answered with disagree or strongly disagree.

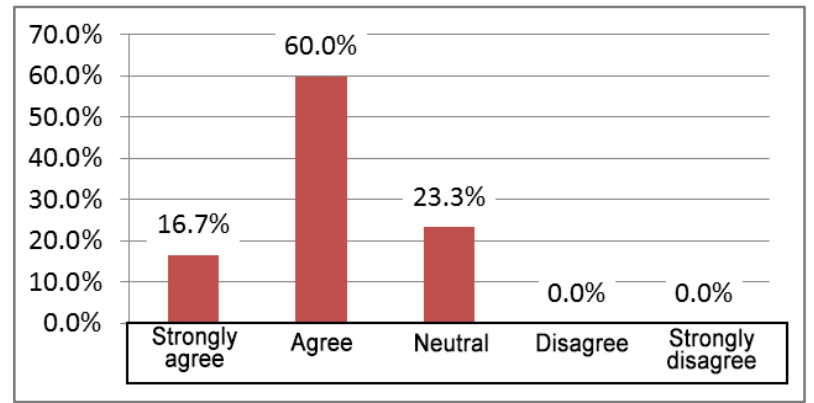

Figure 10. Source: Researcher preparation, from the field study, Excel 2020

3. Does the nature of the population in the Old City affect the Preservation of old housing (renters vs. original inhabitants): The majority of the study participants answered with I agree as their number reached 16 participants, and they constitute 53.3\%, followed by those who answered strongly agree with 7 participants, at a rate of $23.3 \%$, while the number of those who answered neutral 5 participants, at a rate of $16.7 \%$, the participants who answered with disagree or strongly disagree was $3.3 \%$.

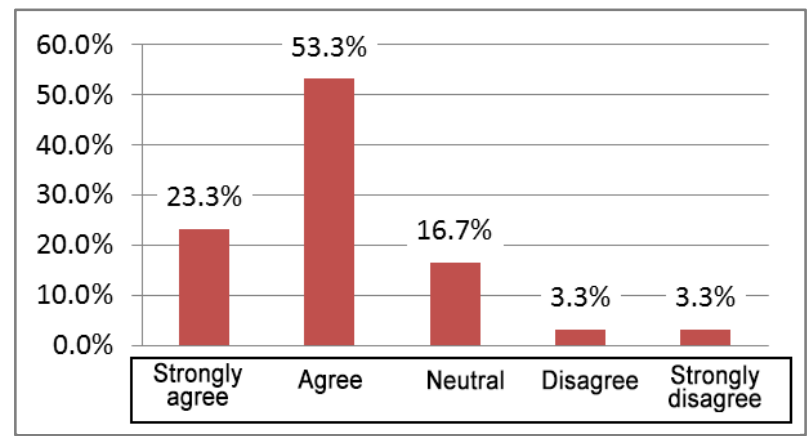

Figure 11. Source: The researcher prepared, from the field study, Excel 2020

4. The technicians supervising the restoration of old housing have sufficient experience to qualify them to carry out maintenance and restoration work: It is evident that the answer for the majority of the study participants is I agree, as their number reached 14 participants and constitute $46.7 \%$, followed by those whose answer was neutral with 8 participants, at a rate of $26.7 \%$, while the number of those who answered strongly agree was 4 participants, at a rate of $13.3 \%$. Participants who answered with disagree or strongly disagree was $10 \%$ and $3.3 \%$ respectively.

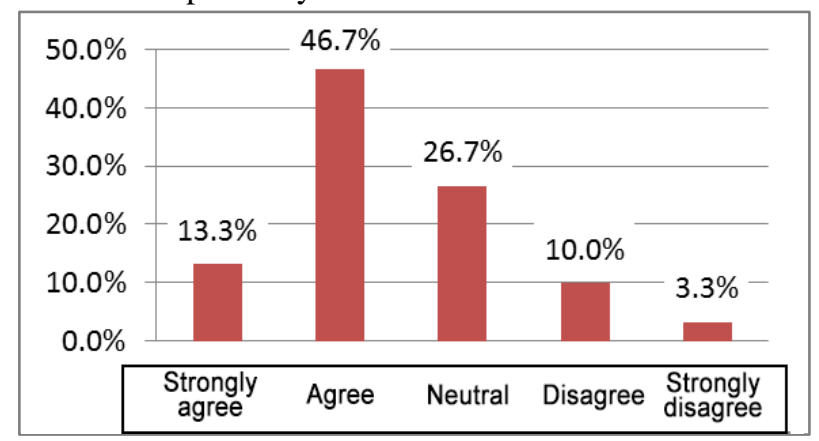

Figure 12. Source: Researcher preparation, from the field study, Excel 2020

5. There are many procedures followed in the process of maintenance of old houses: The answer for the majority of the study participants is I agree as their number reached 16 participants and they constitute 53.3\%, followed by those whose answer was neutral with 9 participants, at a rate of $30 \%$, while the number of those who answered strongly agree were 4 participants, at a rate of $13.3 \%$. The study participants who answered disagree constituted $3.3 \%$ while no participants answered strongly disagree.

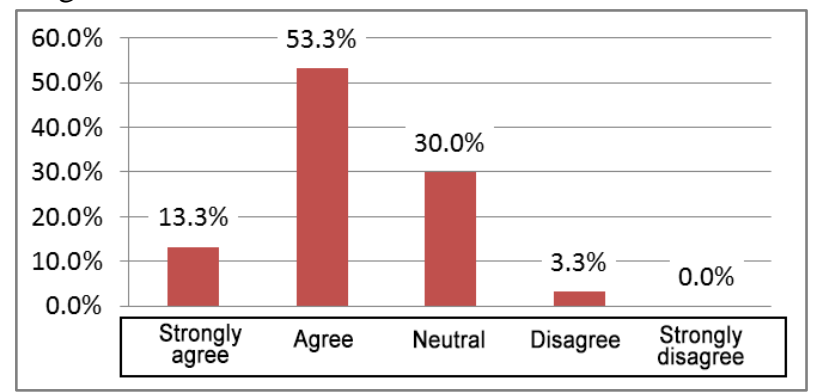

Figure 13. Source: Researcher preparation, from the field study, Excel 2020 
6. The general character of the dwelling is taken into account when it is rehabilitated and it is preserved as it is: It is evident from figure 3-12 that the answer for the majority of the study members is agree, as their number reached 14 participants, and they constitute 46.7\%, followed by those who answered neutral 12 participants which was $40 \%$, while the number of those who answered with strongly agree and those who disagree were two participants, at a rate of $6.7 \%$. No participants answered with strongly disagree.

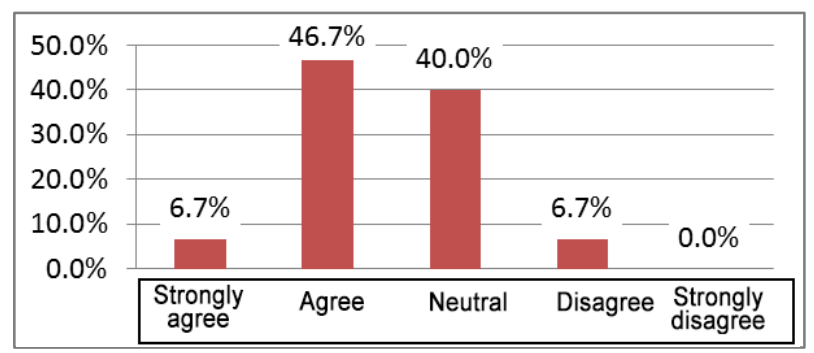

Figure 14. Source: Researcher preparation, from the field study, Excel 2020

7. The current dwellings in the old towns largely meet the needs of the population: It is evident from figure 3-13 that the answer for the majority of the study participants answered with agree with 22 participants and they constitute $73.3 \%$, followed by those whose answer was neutral. With 5 participants, at a rate of $16.7 \%$, while the number of those who answered strongly disagree was 3 participants, at a rate $10 \%$.

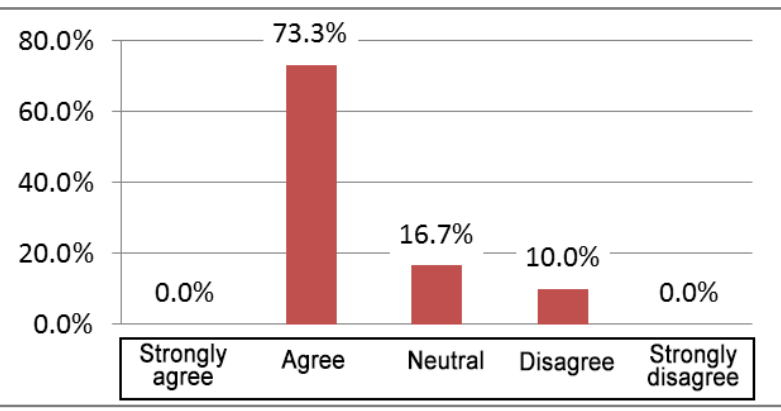

Figure 15. Source: Researcher preparation, from the field study, Excel 2020

8. The old dwellings are as suitable for living as modern dwellings: the majority of the study participants answered with neutral as their number reached 13 participants and they constitute $43.3 \%$, followed by those who answer disagree with 9 participants with $30 \%$, while the number of those who answered agree and strongly disagree was 4 participants, at a rate of $13.3 \%$.

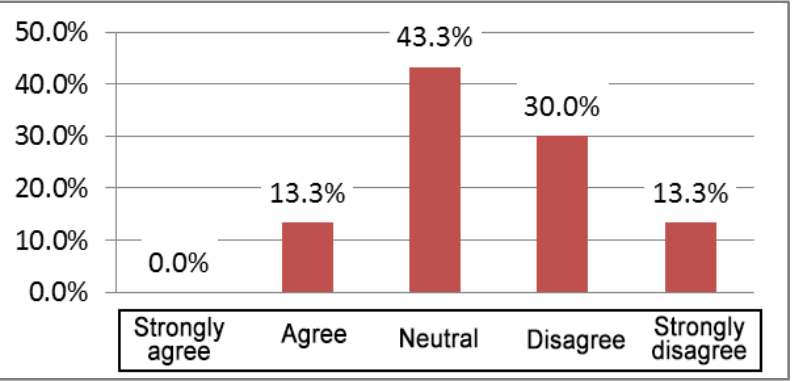

Figure 16. Source: Researcher preparation, from the field study, Excel 2020

9. The majority of the inhabitants of the old towns are considered to be their original inhabitants: The answer for the majority of the study members was disagree as their number reached 17 participants and they constitute $56.7 \%$, followed by those whose answer is neutral with 11 participants, at a rate of $36.7 \%$, while the number of those who answered strongly disagree was two participants, at a rate of $6.7 \%$. No participants answered with agree or strongly agree.

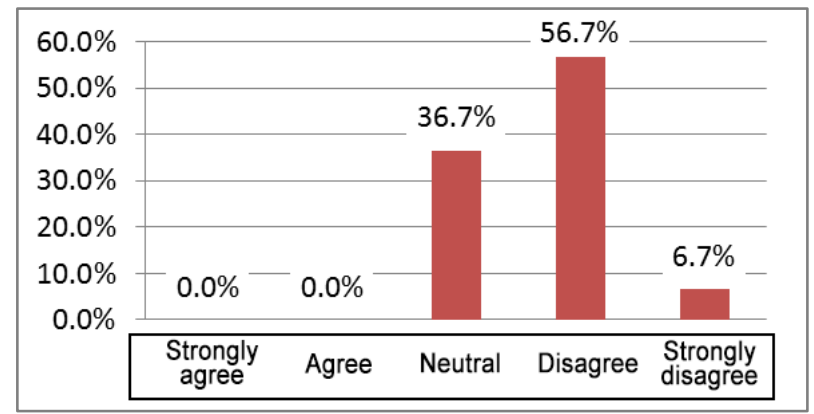

Figure 17. Source: Researcher preparation, from the field study, Excel 2020

10. Recreation and service centres are available in the old towns: The answer for the majority of the study participants was agree, as their number reached 15 participants and they constitute $50 \%$, followed by those whose answered with neutral by a number 10 participants, at a rate of $33.3 \%$, while the number of those who answered disagree 5 participants, at a rate of $16.7 \%$. No participant answered with strongly agree or strongly disagree.

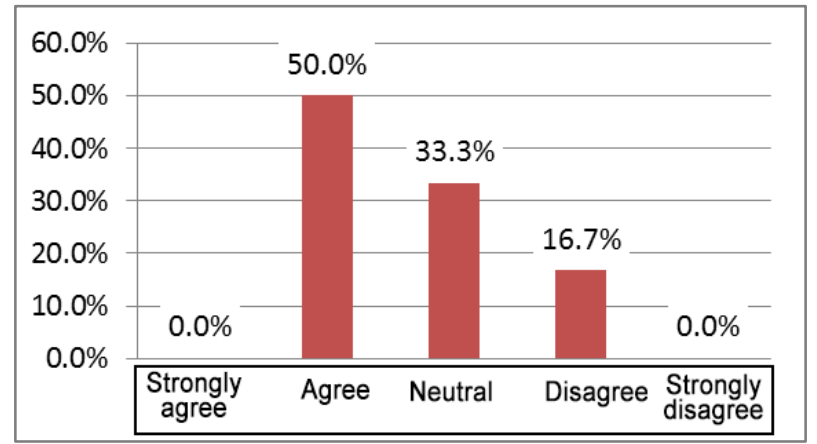

Figure 18. Source: Researcher preparation, from the field study, Excel 2020 
To test for the existence of statistically significant differences between the numbers of respondents, Chisquared test was used to indicate the differences between the answers to each of the phrases.

Table 4 summarizes the test results for these statements.

The third part of the questionnaire: This part of the questionnaire was devoted to measuring the difficulties related to the preservation process and the problems facing housing in the Old City of Hebron. Phrases and questions were chosen in order to reach the answer to the question posed by the study regarding the difficulties faced by the residents of the Old City of Hebron from the point of view of residents and specialists and from the reality of living in the Old City. The phrases came so that the respondents define their statements among the available options.

1. The first statement came: In your opinion, what are the most important problems related to the Preservation of old dwellings: It is evident from table 4 and that the answer for the majority of the study participants, is difficulty in obtaining adequate support as their number reached 17 participants and constituted $56.7 \%$, followed by those who answered difficulty obtaining skilled craftsmen with 12 participants, at a rate of $40 \%$, while the number of those who answered lack of will was one person, at a rate of 3.3\%. figure 19 shows the frequency distribution of the responses of the study subjects.

Table 4. Source: Researcher preparation, from the field study, SPSS program, 2020

\begin{tabular}{|c|c|c|c|c|c|}
\hline NO & For a phrase & $\begin{array}{l}\text { Chi- } \\
\text { squared test }\end{array}$ & $\begin{array}{l}\text { Probability } \\
\text { value (sig) }\end{array}$ & $\begin{array}{l}\text { Median } \\
\text { value }\end{array}$ & $\begin{array}{c}\text { Interpretation of the } \\
\text { respondents' } \\
\text { direction }\end{array}$ \\
\hline 1 & $\begin{array}{l}\text { What the reconstruction committee is doing to } \\
\text { preserve old houses is sufficient to preserve them }\end{array}$ & 6.8 & 0.079 & - & - \\
\hline 2 & $\begin{array}{c}\begin{array}{c}\text { Housing is documented before it is thoroughly } \\
\text { maintained }\end{array} \\
\end{array}$ & 9.8 & 0.007 & 4 & agree \\
\hline 3 & $\begin{array}{l}\text { The nature of the population in the Old City } \\
\text { affects the Preservation of the old dwellings in } \\
\text { terms of tenants or their original inhabitants }\end{array}$ & 25.3 & 0.000 & 4 & agree \\
\hline 4 & $\begin{array}{c}\text { The technicians supervising the restoration of old } \\
\text { housing have sufficient experience that qualifies } \\
\text { them to carry out maintenance and restoration } \\
\text { work }\end{array}$ & 17.7 & 0.001 & 4 & agree \\
\hline 5 & $\begin{array}{l}\text { There are many procedures followed in the } \\
\text { maintenance process for old homes }\end{array}$ & 17.2 & 0.001 & 4 & agree \\
\hline 6 & $\begin{array}{l}\text { The general character of the dwelling is taken into } \\
\text { account when rehabilitating it, and it is preserved } \\
\text { as it is }\end{array}$ & 16.4 & 0.001 & 4 & agree \\
\hline 7 & $\begin{array}{l}\text { The current housing stock in the old towns greatly } \\
\text { meets the needs of the residents }\end{array}$ & 21.8 & 0.000 & 4 & agree \\
\hline 8 & $\begin{array}{c}\text { Old dwellings have everything to live as well } \\
\text { outside }\end{array}$ & 7.6 & 0.055 & - & - \\
\hline 9 & $\begin{array}{l}\text { The majority of the inhabitants of the old towns } \\
\text { are indigenous }\end{array}$ & 11.4 & 0.003 & 2 & strongly refuse \\
\hline 10 & $\begin{array}{c}\text { In the old towns there are entertainment and } \\
\text { service centers }\end{array}$ & 5.0 & 0.082 & - & - \\
\hline \multicolumn{2}{|r|}{ All phrases } & 163.9 & 0.000 & 4 & agree \\
\hline
\end{tabular}

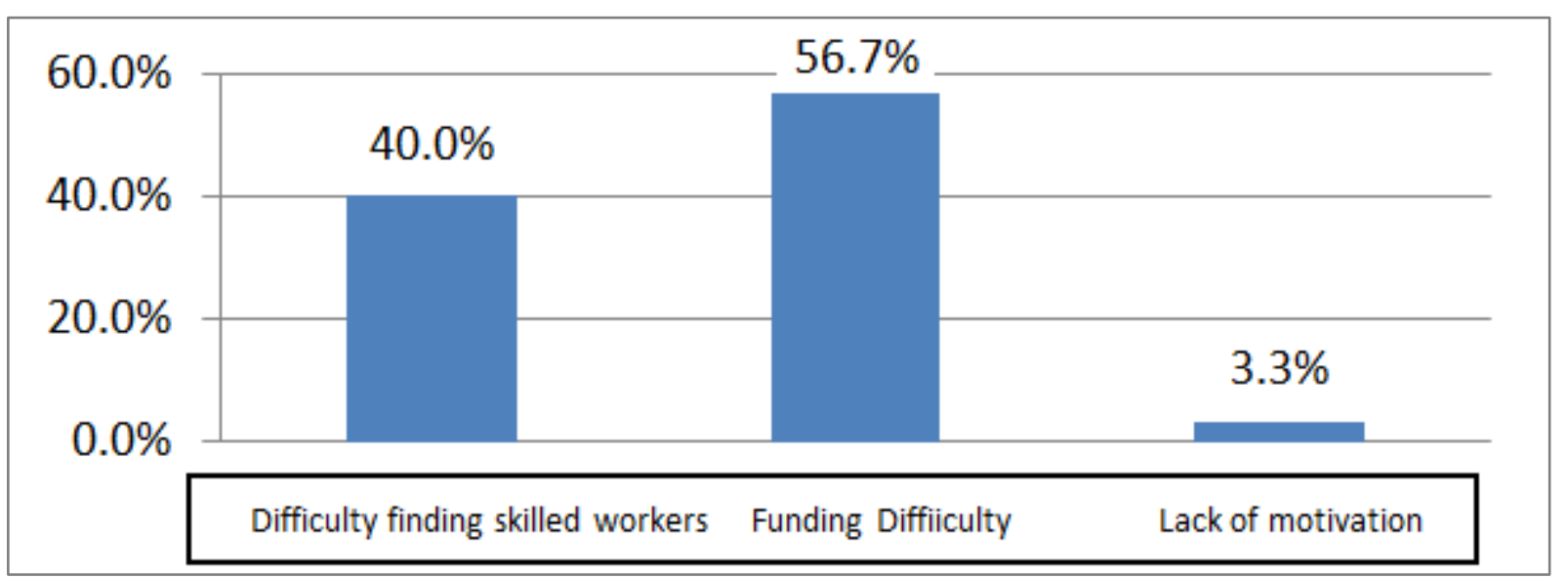

Figure 19. Source: Researcher preparation, from the field study, Excel 2020 


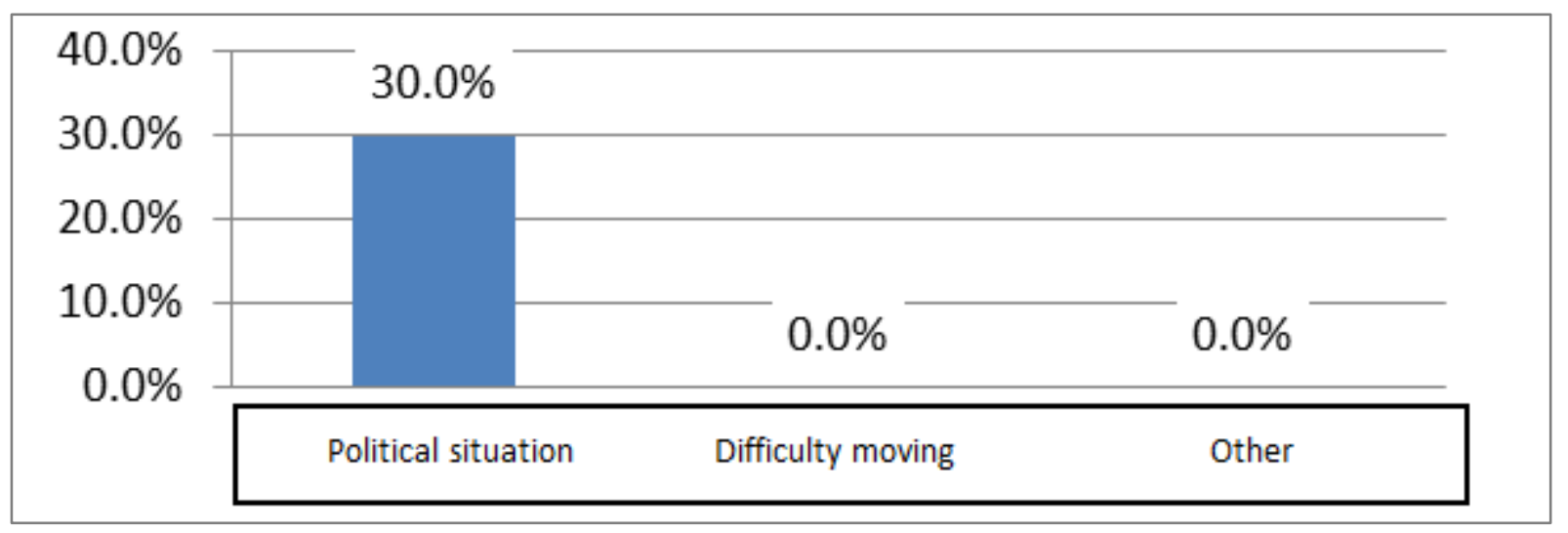

Figure 20. Source: Researcher preparation, from the field study, Excel 2020

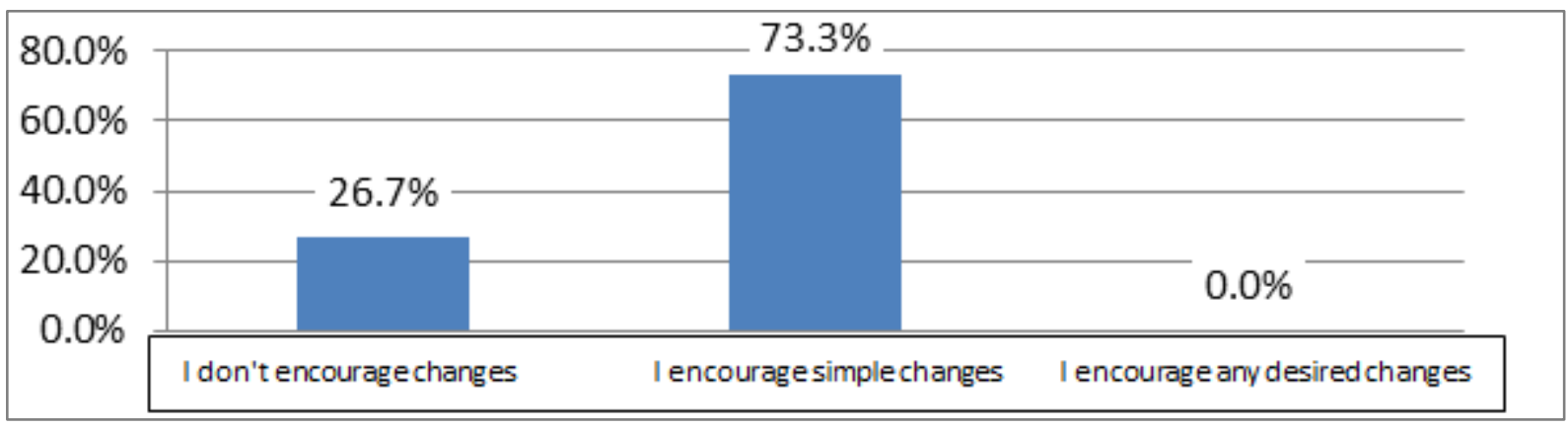

Figure 21. Source: Researcher preparation, from the field study, Excel 2020

2. The second statement, in your opinion, is one of the most important reasons for people migrating to old housing: It is clear from figure 20 that the answer for all the study participants was due to the political situation and the Occupation, as their number reached 30 participants, and they constitute $100 \%$.

3. The third sentence: Do you encourage residents in the old towns to make the appropriate modification to them without referring to the competent authorities: It is evident from figure 21 that the answer for the majority of the study participants is I encourage making simple changes as their number reached 22 participants and they constitute $73.3 \%$, while the number of those who answered I do not encourage making changes 8 participants by $26.7 \%$.

\section{Conclusions and Recommendations}

The questionnaire and case studies of houses in the Old City were meant to answer certain questions; What are the obstacles that prevent reaching the desired goal of preserving the structural structure and the cultural component without harming materials and the cultural essence? What are the difficulties facing housing in the Old City? And as a result of that, what are the impacts adhering to houses in the Old City?

\section{Obstacles that prevent access to the structural elements and the cultural components:}

Human interventions, which were represented in the work of repairs and changing the features of the building, from creating new openings and using inappropriate materials such as clay pores, which closed the stone pores and changed the aesthetic value of the building by hiding the natural stone of the building. The extension of drainage pipes that appear on the facades caused a visual distortion of the building and changed the original components on the single façade of the residential building. The use of reinforced concrete to build columns to add new floors to the building changed the original load ratios and original housing design. Adding zinc roofing to open yards is one of the safeties of this solution. Still, it changed from the original design of old buildings represented by open courtyards in traditional housing. The occurrence of problems in the interior design of the dwelling and the inconsistency of the internal distribution with the basic requirements of the residents of the dwelling and the difficulty of linking the interior spaces and furniture and the inconsistency in their design. The natural problems that the old dwellings suffer from, such as rain, earthquakes, dampness, and Kahlah, constitute a continuous challenge in the maintenance process of the residential buildings to be preserved. 


\section{Housing Challenges and Difficulties and Its Effects:}

The Reconstruction Committee preserves and maintains old houses in the Old City of Hebron, and it also undertakes the process of documenting housing before it is acceptable maintenance. The nature of the population in the Old City affects the process of preserving the old houses in terms of whether they are renters or their original inhabitants, so the houses maintained by original residents are in a better condition than the rented ones. Technicians and supervisors for the restoration of old housing need more experience that qualifies them to carry out maintenance and restoration work. And that there are many procedures followed in the process of maintenance of old homes. The preservation process needs more studies related to the general character of the dwelling when it is rehabilitated. The difficulty of obtaining adequate support is one of the most important problems facing the conservation process, followed by the difficulty of obtaining skilled craftsmen.

One of the most important reasons that lead to residents leaving and abandoning their homes is the political situation and the Occupation. It is one of the biggest problems facing the governing process in the Old City of Hebron. The preservation process faces the problem of the changes that citizens make to old dwellings that harm the residential building structure and lead to visual pollution.

\section{Recommendations}

Supporting the efforts of the Reconstruction Committee to preserve the cultural and structural fabric of old houses, restore and rehabilitate them for housing awareness of the importance of preserving the cultural fabric and paying attention to it. Supporting studies that support the preservation process and support adaptation to housing in old housing. A call for interior designers and engineers to support ideas for residential solutions, including solutions for interior furniture and interior components such as floors, walls, etc. to reinforce old residences, which help in the preservation process and the suitability for housing in them.

\section{Summary}

Preserving cultural property is an important part of preserving identity, which forms a part of our personality. Our goal must be the preservation of these properties and it should stem from a desire to help preserve cultural heritage, support restoration and rehabilitation projects, such as those done by the Hebron Rehabilitation Committee.

\section{REFERENCES}

[1] Marina V. Knyazeva , Sergey V. Mokhovikov , Lidiya V. Alekseenko, Natalia S. Bryazgunova , Genadiy B. Baranov , "'The Singing Building" in the Ryazan Kremlin (XVII-XVIII Centuries): A Strategy for Preserving the Object of Cultural Heritage," Civil Engineering and Architecture, Vol. 9, No. 1, pp. 130 - 138, 2021. DOI: 10.13189/cea.2021.090111.

[2] Feilden .Bernard M. Conservation of Historic Buildings Third edition Kt, CBE, D Univ, D Litt, FSA, FRSA, AA Dipl(Hons), FRIBA Director Emeritus, International Centre for the Study of the Preservation and the R First published 1982 Revised paperback edition 1994 Third edition 2003 British Library Cataloguing in Publication Data.p3

[3] Abu Hantash, Noha Ahmed. Towards a policy of rehabilitating residential buildings in Palestinian city centers, a case study in Nablus. Master Thesis. An-Najah National University. Nablus, Palestine, 2007.p25

[4] Iman Assi. Cultural Heritage and Sustainable Development: The Role of Local NGOs in Rehabilitation of Historic Cities in Palestine. An-Najah National University, Nablus. Palestine, 2006.

[5] Amira Elnokaly1. Ahmed Elserag. 2, 31. Sustainable Heritage Development: Learning from Urban Conservation of Heritage Projects in Non-Western Contexts. European Journal of Sustainable Development. 2013

[6] Al-Alimi, Mujir al-Din al-Hanbali. The Great Insanity of the History of Jerusalem and Hebron. Second volume. Achieving Mahmoud Al Kaabneh. Supervision of Dr. Mahmoud Ali Atallah. First edition. Dendes Library - Hebron. Palestine, 1999.

[7] Al-Dabbagh, Mustafa Murad. Our country, Palestine, C5 Section Two. Diyar Al-Khalil. Dar Al-Hoda - Kafr Qara. Palestine, 1991.p50-49

[8] Abu Laila. Muhammad Muhammad. Shawqi. and Al-Barqawi. Wadih bin Ali. Methodologies for preserving the urban and architectural heritage in the Arab countries. International Journal of Architecture, Engineering and Technology, 2019.p129.

[9] Amr, Nu'man, the city of Hebron during the Mamluk period 648-922 / 1256-1157. A working paper submitted to the Conference on Urbanism in the City of Hebron and the Cultural Heritage. Arab World Institute - Paris, Al-Quds Open University. 25-26/11/2011.p20

[10] Halabiya, Hamza. Settlement and the wall in the city of Hebron. Vision Center for Political Development, the settlement chain and the wall. 2-25 2020.p17

[11] Awad, Jihad. The experience of preserving the architectural heritage in Palestine. Journal of Science and Technology Volume 13 Issue 1. 2008.p23

[12] Shash, Shawky. Islamic architecture in the Ayyubid era. Palestine Encyclopedia of Culture. -Yasser Arafat Foundation 5/11/2017 Hebron Rehabilitation Committee, Online available from https://yaf.ps/page-650-ar.htm.

[13] Atma, Muhammad Allam Fawzi. Rehabilitation of historical buildings in Palestine: a case study, Nablus. Master Thesis in Architecture. An-Najah University. Palestine, 12/12/2007.p12. 
[14]Feilden and Jukka. Bernard. Management Guidelines for World Cultural Heritage Sites B M Jokilehto ICCROM Second Edition Rome, 1998.p4.

[15] Al-Khudairi. France 24 What is the importance of the city of Hebron, which UNESCO considered as an "exceptional global value", Online available from https://www.france2 4.com/ar/20170707.

[16] Hebron Rehabilitation Committee. A comprehensive plan to preserve and revive the Old City of Hebron. Publications of Hebron Rehabilitation Committee. Palestine, 1/19/2016.p8.
[17] Ministry of Tourisms and and Antiquities. State of Palestine State of Conservation Report for Hebron/Al-Khalil Old Town - Palestine (SOC) for the World Heritage Property (WHP). close cooperation with Hebron Municipality, and Hebron Rehabilitation Committee, Jan.2019.p3.

[18] almisri, Majd Najdi Nagy. Assessment of restoration methods and techniques in Palestine, Nablus, a case study. Master Thesis, An-Najah National University. Palestine, 2010.p26. 